\title{
Independent Village Development
}

\author{
Fandi Ahmad* \\ Human Resource Management Apparatus \\ STIA LAN Bandung Polytechnic \\ Bandung, Indonesia \\ *ahmad_fandi@rocketmail.com
}

\author{
F. Laksmi Fitriani \\ Public Sector Business Administration \\ STIA LAN Bandung Polytechnic \\ Bandung, Indonesia
}

\author{
Iwan Kurniawan \\ State Development Administration \\ STIA LAN Bandung Polytechnic \\ Bandung, Indonesia
}

\begin{abstract}
Covid 19 pandemic outbreak has slowed down the economy and even fell into a recession. The government is trying to focus on economic recovery efforts by encouraging development so that each village can cultivate the potential that exists in its area to create economic independence without expecting any more programs or assistance from the government. This type of research uses a descriptive qualitative approach by utilizing data from the results of field interviews, observations and coupled with literacy studies. Researchers try to cluster the potential of villages in Bandung district by processing data sourced from the national statistical agency to determine the potential in the village and the proposed development is based on a cluster approach and is based on the results of data processing, it is known that several phenomena as well as several issues arise and conduct field observations to compare data with phenomena that occur in the field to try to formulate solutions for village development in order to create an independent village, from the research results it is known that there are several proposals, namely through distribution through village potential clusters which are to make programs that are more focused and directed in increasing economic growth, then there is a need for information in management existing human resources in the village to create competencies which in turn can help the village, especially in an effort to get out of the current economic pressure.
\end{abstract}

Keywords-independent village, transformation, human resources

\section{INTRODUCTION}

The current rural condition has become a full concern in the era of Jokowi - Jusuf Kalla administration for 2014 - 2019. Through the NAWA CITA program which consists of 9 (nine) flagship programs, one of which is the 3rd program, namely: "Building Indonesia from the Outskirts with Strengthening Regions and Villages within the Framework of a Unitary State" [1]. With the NAWA CITA program, of course there is great hope for improving the quality of development, both physical and non-physical, starting from villages in the territory of the unitary republic of Indonesia.
The President of the Republic of Indonesia explained that villages can become a buffer when there is an economic crisis in cities due to the Covid-19 pandemic [2]. Seeing from the comparison of the spread of Covid-19 that is hitting Indonesia, cities have a very high distribution intensity compared to villages. This is in line with what was expressed by a member of the Satuan Gugus Tugas Covid-19 (Satgas) Dewi Nur Aisyah that positive cases of Covid-19 in urban areas contributed higher numbers when compared to districts [3]. Therefore, this condition becomes a momentum for the village to develop its potential in the fields of agriculture, tourism, and industry. In addition, the government has started to aim towards the periphery by strengthening areas and villages, so that it will have an impact on rural communities, and employment in villages will also grow and develop according to the expectations of people in rural areas, especially in West Java Province.

\section{METHODS}

This type of research uses a descriptive qualitative approach by utilizing data from the results of field interviews, observations and coupled with literacy studies, researchers try to cluster the potential of villages in Bandung district by processing data sourced from the national statistical agency to determine the potential in the village and The proposed development is based on a cluster approach and is based on the results of data processing, it is known that several phenomena as well as several issues arise and conduct field observations to compare data with phenomena that occur in the field to try to formulate solutions for village development in order to create an independent village

\section{RESULTS AND DISCUSSION}

\section{A. Human Resources}

Humans are a core resource in the process of activities in an area, so that human resources are a very valuable aspect and 
potential for an area to manage existing natural resources. The determining factors in village development can consist of the level of education, skills and enthusiasm of the people living in the environment.

Informal HR development, namely developing the quality of human resources individually based on their own awareness and desire to improve their quality in relation to their duties. There are many ways that human resources can do to improve their abilities, but this type of development requires a strong intrinsic motivation and the ability to access information sources as learning resources. For example, the relationship between the quality of human resources and the effectiveness of using SISKEUDES refers to research conducted by Caecilia and Marthen [4].

Upskilling for digital does not just teach you how to use a device. because a device will be obsolete for years to come. The most important thing is a memorable experience because it involves a way of thinking, developing and acting, in a sustainable digital world from time to time [5].

The existence of a new era 4.0 forces people in an area to be able to adapt to be in line with the increasingly fast flow of information and to be able to adapt well, people are required to have competent human resources (HR) who can understand and utilize the internet well as well. With the era of globalization, there will tend to be problems if there are no qualified human resources. Sources of problems that underlie the emergence of the digital divide include difficulties in access (electricity, telecommunications, equipment), lack or limited skills (human resources, community), lack of content, and lack or lack of support from the government [6].

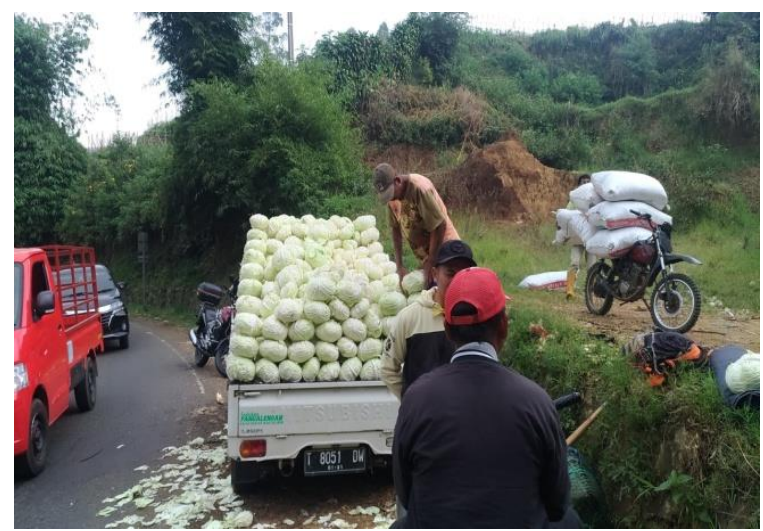

Fig. 1. Transportation of plantation products in the Pangalengan area.

However, in this pandemic situation, the whole community is also affected, such as in the tourism sector, the level of visits has dropped dramatically so that at the lodging place the manager takes a policy to try to make activities more efficient and minimize expenses, including reducing working hours to reducing employees. This is due to the fact that some tourism places have closed within a few months due to avoiding the spread of Covid 19, then from the agricultural, livestock and plantation sectors are also affected. This is because the supply chain of raw materials to big cities is hampered due to large- scale restriction policies (PSBB) resulting in an overstock so that product prices fall, then this is exacerbated because this sector does not have sufficient storage or storage to store production results so that many agricultural commodities are rotten and result in significant losses.

\section{B. Human Resource Management in Village Communities}

Facing the conditions and challenges that exist today, it is necessary to develop governance, especially from the human resources side, because it can then be used as a strong foundation to support a program and become a benchmark or indicator of an area if you want to change and become a winner of the competition. is by training in the management of human resources in the village properly, increasing skills in managing human resources is an effort that can be made by the leader of a region in managing his community, in this case it can be done by training methods on human resource management in community activities. such as planning the number of workers needed, selecting or selecting human resources according to their expertise and interests, training on farming skills and controlling the performance of each related human resource. for example, planning, especially planning about the number of personnel involved such as how many workers are needed, what they will do or what work they will master, the level structure of what will be built and everything related to the needs and specifications of the human resources required.

\section{Directions and Strategies in an effort to Improve Human Resources in the Village}

To achieve an independent village, several strategic steps are needed, especially in developing human resources, increasing empowerment and forming the socio-cultural capital of rural communities that can be implemented through the following strategies:

- Develop skills-based education.

- Give recognition, respect, protection and promotion of community rights

- Develop the capacity and assistance of customary institutions in a sustainable manner.

- Increase community capacity and participation through facilitation, training and assistance in planning, implementing and monitoring village development.

\section{Upgrading Farmers' Skills in Utilizing IoT}

The Tricipta Farmer Group is one of the farmer groups in Mekarmanik Village, Cimenyan District, Bandung Regency, West Java Province. This farmer group was initiated by $\mathrm{Mr}$. Oden Suganda with 32 members and 100 assisted people and focuses on agricultural commodities such as shallots, potatoes, chilies, and cabbage with an arable area of about 500 hectares.

In 2016 when there was a fluctuation in the price of shallot commodities, the market reached 80 thousand rupiah, even the price in the capital reached 120 thousand rupiah, for this 
reason, the Tricipta farmer group was given a mandate from the government to assist government programs, especially in controlling the price of onions, then farmer groups This is trying to pour the yield of 150 tons directly to the market in the hope that it can reduce the price of onions even though on the way there are some members who protest because they sell prices far from the market, but after being given an understanding and avoiding imported onion products from entering Indonesia, they finally support the program It is proven that after direct market operations have made prices fall and become the superior onion granary of the Ministry

This success has led to full trust and support from both the government and the private sector collaborating with each other through the CSR program, Habibi Garden collaborated with DISKOMINFO Jabar, JABAR Digital service and the Office of Food Crops and Horticulture of West Java Province to create the first digital village concept in West Java with focus on onion and integrated technology-based agricultural centers or it can also be called smart farming, in which farmers who are included in the Tricipta farmer group are given guidance in land management by utilizing applications so that farmers will focus more on plant maintenance. See figure 2 below.

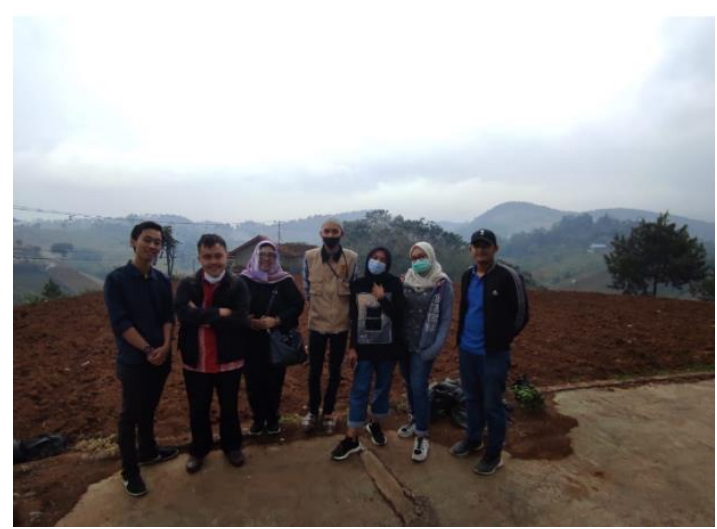

Fig. 2. Field observation of the first digital village program in West Java.

For the learning process of the digital farming method, it is felt that there are no obstacles, this is because farmers are actively involved, especially during the process of applying technology such as installing pipes, sensors, water storage containers, and several other components in the field, then farmers are invited to discuss and be given assistance in the process is like how the nutrients are dissolved in a water container and then watered on the land, then the deepening of the planting method takes advantage of the Garapan meeting which takes place every 2 months, especially before starting the planting process of planting seeds coupled with meetings from agencies, ministries, and visits from academics so that farmers can find their own way out if there are problems in the future. See figure 3 below.

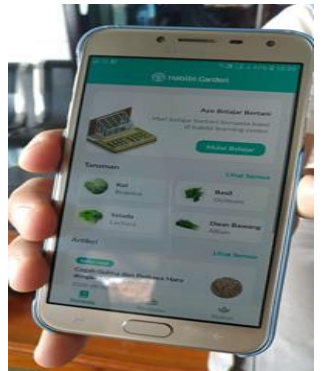

Fig. 3. Use of the Habibi Garden application for monitoring agricultural land.

This application is considered very useful because from this application farmer can find out information about humidity levels, light intensity, information on nutritional conditions in plants, for example the nutrients in the land are lacking, a notification will automatically appear on the farmer's cellphone. to immediately provide fertilizer to plants, then this application also provides several conveniences such as farmers can still water the plants even though the distance between farmers and land is far away so that the agricultural process becomes more organized and farmers can focus more on maintaining plants, with the existence of this can directly provide the effect of using resources that are more effective and efficient than the traditional method, with the output of agricultural products that is more than the previous method. Then it can form a new view that farmers are millennial jobs because they are assisted by using the IoT system, so that it is expected to spur young people to want to descend into the next generation of farmers.

\section{E. Economic Challenges During a Pandemic}

With the Covid-19 outbreak that occurred in Indonesia, almost all business industries felt the impact, almost all the income that companies usually get is currently being corrected and finally many companies choose to close their businesses, with this condition also changing consumer behavior, like consumers who usually accustomed to shopping and conducting transactions in markets or other public spaces is now starting to change more to consumption using the internet and this is a very tough challenge going forward, because apart from facing a pandemic, pandemic conditions like today, every business actor must be able and quickly make adjustments to its business processes to keep it running and survive. Every business actor must have the ability to adapt and innovate by looking for new business ideas that are especially suited to current conditions.

Response to customers is a new demand that is a key success factor in business, there is competition, especially in integrated technology mastery and is a must-have for companies. If you want to win the competition, technology creates a fast response and this can happen by involving all stakeholders. interests ranging from the public sector, private sector, academics, to the wider community so that the current Covid-19 pandemic can create well-managed industrial business construction 4.0 so that it becomes new opportunities. 
By looking at the field phenomenon and some of the previous discussions, researchers can provide several opportunities from the use of technology that can be felt to maximize opportunities, especially in the midst of conditions like today:

- Online-based Business Model as previously known, advances in technology and information can be used as opportunities to build new businesses, with the development of technology it can be used as an innovation to develop a bigger business, changes in consumer behavior can be used as new opportunities to encourage business actors to expand their business, for example. When viewed from the agricultural side, farmers can take advantage of several social media to provide information to consumers, consumers are not only given information about the goods or prices of the commodities being marketed, but consumers can also be given education in it about how to plant, how to treat plants, the growth process to monitoring the plantation process so that if this is done, not only buying and selling transactions will arise but there is a process of bonding and trust between farmers and consumers so that market demand will continue and if the process is deep The agricultural land runs optimally, so it is possible that the business process will expand and farmers will no longer have difficulty selling the goods they produce.

- Reducing Expenses with the use of information technology in business processes, the required capital can be reduced because of the efficiency of time, energy and resources, and this has proven its benefits, such as in the agricultural system in Tricipta farmer groups.

- Communication Easier In order to create a large company, it needs to be supported by a solid team with the use of information technology, it will make communication between individuals in an area or group easier to do, and safer because it minimizes direct physical contact and from the monitoring side it will also be facilitated by the existence of the use of information technology, for example in conducting meetings or meetings, can take advantage of the zoom application so that it can be done anywhere and anytime and is not limited by the problem of space and time distance, so as to save time, effort and costs.

- Product Marketing Media Becomes Broader. In business process, marketing is the most very important aspect. Where with good marketing, the market shares of the products produced can be wider, businessmen can use online and social media as a forum to explore their products, provide information and even feedback to consumers.

\section{CONCLUSION}

Management of the environmental system in the village during a pandemic by implementing health protocols. The application of health protocols is the obligation of all elements of society, be it the government as the public organizer or the village community. The application of this protocol is part of village development towards an independent village so that it can overcome the risk of disasters that occur in the community.

Human resource development is still being carried out in the village by implementing health protocols or looking for other alternatives. One alternative is collaboration and the active role of all parties, especially in developing agricultural science, economics, and technology in the form of discussion forums, scientific seminars, and online forums so that the use of resources is more effective and efficient. The use of technology is also an alternative for other human resources. With collaboration, the generation gap can be resolved against the use of technology. Some millennial farmers have used applications in field management so that they are effective and efficient. Millennial and colonial farmers cooperate in the management of agriculture, livestock and plantations by utilizing technology, especially marketing agricultural products and the location of tourist attractions (agrotourism). Not only agrotourism marketing, tourism in the form of nature, entertainment, culinary, and others can be applied.

\section{REFERENCES}

[1] B.P. Nugroho, "4 Tahun Jokowi-JK dan Realisasi Nawacita," [online]. Retrieved from https://news.detik.com/berita/d-4265140/4-tahunjokowi-jk-dan-realisasi-nawacita.

[2] A.D. Tolok, "Jokowi: Pandemi Harus Jadi Momentum Tingkatkan Ekonomi Desa," [onlibe]. Retrieved from https://ekonomi.bisnis.com/read/20200924/9/1296020/jokowi-pandemiharus-jadi-momentum-tingkatkan-ekonomi-desa.

[3] D.E. Nugraheny, "Satgas: Perkotaan Lebih Banyak Sumbang Kasus Covid-19 Dibanding Kabupaten," Kompas.Com, [online]. Retrieved from https://nasional.kompas.com/read/2020/08/19/11112911/satgasperkotaan-lebih-banyak-sumbang-kasus-covid-19-dibanding-kabupaten.

[4] C.H.S. Wati and M.A.I. Nahumury, "Pengaruh Kualitas Sumber Daya Manusia Terhadap Nilai Informasi Laporan Keuangan Pemerintah Daerah Pada Kabupaten Merauke,” Jurnal Ilmu Ekonomi \& Sosial, 2014.

[5] B. Moritz, "Preparing everyone, everywhere, for the digital world.PWC," [online]. $\quad$ Retrieved from https://www.pwc.com/gx/en/issues/upskilling/everyonedigitalworld.html\%0D

[6] A. Hubeis, "Perilaku Masyarakat Dalam Pemanfaatan Information And Communication Technology Dalam Mendukung Pengembangan Masyarakat Global,”Jurnal Komunikasi Pembangunan, 2010. 